\title{
Conclusions: Linking the Local to the Supralocal ${ }^{1}$
}

Orri Vésteinsson

\section{Stuart Brookes}

Julio Escalona

Medieval history is full of kings and knights and bishops and scholars and poets, and their lives, battles and intrigues seem to play out in worlds of their own, as if suspended over the worlds of ordinary people with hardly anything connecting the two. Courts, battlefields and cathedrals feel far removed and isolated from the toiling masses of peasants who-if they appear at all-figure as a constant, unremarkable and dull background to the busy lives of the elites. When research does focus on the worlds of peasants, however, they turn out to be anything but dull; rather they appear as immensely colourful, dynamic and variable, but the same sense of separation is apparent when the Middle Ages are viewed from this angle. The perception is that the everyday lives of ordinary people, in farms, hamlets, villages and even cities, took place in a dimension separate from that of their lords - and that it mattered little for those everyday lives what the rulers were up to. The dictum of Swedish historian Erik Lönnroth that in the early Middle Ages ordinary people generally experienced their government only as a passing catastrophe, ${ }^{2}$ catches this sense of disconnection quite succinctly; whether the 'catastrophe' was as a result of warfare or an occasional visit by a peripatetic court is secondary to the argument.

This characterization has a ring of truth about it, but the project that this book derives from started with the explicit aim of challenging such a dichotomy. By emphasising the separation between localities and higher political spheres we risk portraying the former as essentially passive backgrounds whose sole function is to provide the material support for social complexity, while the processes by which the latter formed and developed are clouded in mist. Indeed, this problem is particularly pronounced when studying the formative phases of polities, when governments lacked the basic resources to exert largescale control over localities. The contributions in this book contest that the connections and the exchanges between these two spheres is a topic in need of wholesale revision.

Whether the authors have succeeded in this task is for readers to decide. We believe our main goal will have been achieved if the book manages in some way to counteract the prevalence of top-down readings of the textual evidence and all-encompassing notions of belonging, such as ethnicity and political identities, in current explanations of social and political change in the early Middle Ages. As the role that social acceptance played in legitimating political authority is increasingly seen as a crucial dimension of light-weight political systems, the interaction between political powers and the localities—or the lack thereof-becomes a major issue to consider.

Perhaps here is the place to reflect upon what has and hasn't been achieved by this project. Firstly, and most obviously, we are conscious that we have hardly scratched the surface of issues so large that it would be unrealistic to think they can be 'solved'. This is another case in which asking the questions may be more important than answering them. We strongly believe that the concerns and approaches that shape this volume should be

\footnotetext{
${ }^{1}$ This text has been prepared with support from the FES2 research project (HAR2010-21950-C03-01), funded by the Plan Nacional de I+D+i. of the Spanish government.

${ }^{2}$ Lönnroth, 'Government in Medieval Scandinavia', p. 455.
} 
considered by other scholars when reflecting upon general issues of early medieval social complexity.

These concerns can also be taken into other directions to provoke different answers, as indeed they are by the contributions to this volume. These papers demonstrate a great diversity: in the geographical and environmental contexts of their subjects, the societal developments they describe, and the sources they employ. They range widely in spatial and temporal scale. For the periods under consideration, the available evidence is often remarkably thin, so that sometimes it is not possible to drill down into localities, and wider perspectives need to be taken. Similarly, especially when charters are the main source of evidence, the level of detail these provide allows for much shorter time-scales to be examined than when archaeology is the only source.

However, it does not just come down to differences in the nature and density of the evidence. As has emerged from previous studies by this group, early medieval societies were incredibly diverse. This means that any comparative exercise needs carefully to consider the specific contexts, scales, practices and backgrounds operating in different times and places. Moreover, the studies in this volume show that both early medieval societies as a whole, and the localities within them, were anything but static. Crucial changes took place at all levels during this period that modified dramatically the notions of the local and the supralocal and the interactions between both.

In this book some of the contributors chose to analyse directly the forms of linkages that existed between the local and the supralocal, while others focused on specific local contexts in order to unveil traces of the wider social structures acting upon them. Top-down impact is, unsurprisingly, more readily visible across the volume. Sometimes this manifests itself as political agency driven by rulers from the centre. For example, the ability to create administrative divisions is highlighted as a factor in the emergence of central authority and, therefore, a suitable indicator of state formation processes in regions of northern Europe such as Norway (Iversen) and Anglo-Saxon England (Brookes and Reynolds). At other times, top-down agency is more subtly expressed through high-status private actors (mostly aristocrats) or ecclesiastical institutions, that operate within frameworks of social hierarchies and wide-ranging legal notions of landholding supported by the overall political system. Here, the emergence of large-scale landownership appears to be a major development, whether it is seen through a study of supralocal territories in southern England (Langlands) or within the Asturian and Leonese villages (Fernández Mier, Carvajal, respectively). Indeed, in Ten Harkel's study of Walcheren, it is the interplay of different top-down agencies-distant monasteries and secular rulers-that is expressed in the locality. Generally speaking, the combined impact of political government and aristocratic interests, far from being a zero-sum relationship, as is often thought, seems to have redefined dramatically the notion of the local in many regions of Europe, albeit with different timings and intensities.

This impression must nevertheless be nuanced, because the connections that existed between the local and the supralocal were seldom one-directional, even if the active role of localities is much less visible when compared to that of rulers, lords and Church. Across the volume, we have explored at least two major ways by which localities affected complexity and political centralization. On the one hand, their internal structures can operate as limiters of royal and aristocratic agency, as is clear in the role that local and 
micro-regional assemblies took in shaping the political society and legitimating rulership in the North (Iversen; Brookes and Reynolds). A different, less obvious constraint is discussed by Escalona, regarding how local knowledge existed at the interface of large-scale actors' intrusions into localities, mainly in property transfers.

In both cases it is shown that the degree that localities are able to limit top-down agency depends as much on the internal coherence of communities, as it does on the ability of rulers to override local constraints. The development of centralized methods of territorial survey, for example, can replace or minimize the need for local knowledge. Such capacities are on occasion remarkably precocious (for example, Carolingian polyptics, or Domesday Book), but in general, it took until modern times for European states to develop the cadastral systems that make them so locally omnipresent today. Regarding territorial divisions, Brookes and Reynolds' distinction between regions where the existing traditional territories-areas where the inhabitants have a sense of forming a group-became administrative divisions, and others, where wholesale redrawing of boundaries and regrouping of localities, took place, illustrates well the two-way dialogue between polities and localities, their relative positions to each other, and how these change over time. As for assemblies, the northern case-studies reveal a trend by which most local meetings became separated from the higher levels of political decision-making. Scale seems here to have been a crucial factor: the larger and more layered a polity grew, the more able it was to operate without recourse to its local voices. As the influence of local assemblies waned so their business gradually restricted itself to local administrative issues, and sometimes the symbolic role of ritual legitimation (Iversen). In this way, northern assemblies can be contrasted with those of Visigothic Iberia. Vigil-Escalera makes a case for the existence of micro-regional assemblies that were highly important for the everyday functioning of rural society, but such large-scale gatherings were totally devoid of any higher political relevance to the point that they hardly even feature in the legal texts of the period.

On the other hand, bottom-up agency is expressed through a wide range of cultural traits that become a part of how local society works. Far from isolated systems, localities can share the general principles of organising society as a whole, such as basic notions of political identity and belonging, the legitimation of governance, and the maintenance of social order. It is an important question to ask to what extent central powers actively conveyed and enforced such participation, or whether they emerged from the willingness of local actors to believe in these principles? Davies documents how quite specific scribal conventions survived through a lengthy period of decentralisation in northern Iberia, when the supralocal authority that used to underwrite such conventions and provide them with legitimacy had long ceased to exist. One might read this simply as ingrained conservatism; an appeal to tradition as a means of conferring legitimacy on a transaction. But the observation that when supralocal authorities reasserted themselves again in this region in the tenth century, and seamlessly reappeared as guarantors of these self-same practices, suggests that local actors had maintained the idea of a societal superstructure. Although the institutions that had embodied that superstructure had disappeared, the idea of it remained as the necessary framework for the communities' continued functionality; it ordered people's lives and relationships across communities. Vésteinsson applies the same suggestion to the political sphere, by arguing that the idea of a political superstructure, with the Norwegian king at its apex, provided the framework for local politics in twelfth-century Iceland. In this case, while the institution existed, it was in no position to intervene directly in the locality that nevertheless looked to it for leadership. 
This observation has important theoretical consequences. In a part of the world where political developments are best described by secondary state formation, the ways in which elements of bygone statehood could survive embedded in local society suggests a strong level of basic durability that needs to be taken into account when explaining later political changes. Ten Harkel similarly finds that when ringforts built in the Scheldt estuary in the Viking Age are viewed in their local context they look less like the project of a central authority and more like the products of competition between local and supralocal interests.

Links between neighbourhoods and polities did not only flow back and forth, the two often fed into each other as well. An example of such feedback is provided by Carvajal's discussion of the nomenclature of properties and rights in early medieval León. A shared, accurate terminology was necessary for successful communication between local and supralocal parties. The widespread use of very particular terminology worked in the interests of rulers-facilitating bureaucratic methods of government-and major landowners who had limited personal involvement in the neighbourhoods and needed state-like institutions to safeguard their interests. However, the same terminology-and their underlying rationale-was also maintained by widespread networks of lower-level interests, including both small landowners operating across neighbourhoods within regions, and neighbourhood leaders interacting with their peers on the regional level. We tend to underestimate these kinds of relationships because sources relate primarily to the elites, but one conclusion of this volume is that the close reading and analysis of surviving records often shows that local actors could be equally sophisticated in their use of legal and bureaucratic tools. Likewise, Astill discusses evidence for changes and variability in land use and settlement patterns in early medieval England, in the context of growing signs of political centralisation. Traditional top-down approaches emphasise the rise of the manorial economy as the engine of this process. Astill suggests instead that the great dynamism and variability that is visible from one region to another and within regions, is better explained by considering, not only an increased presence of central authority, but also local responses to changing circumstances. Neighbourhoods adapted to developments at the supralocal level in ways that seemed logical to them, by adopting innovations and responding to the proliferation and impact of urban markets.

Perhaps because the project aimed to investigate local to supralocal connections, this volume gives little consideration to cases where such links were relatively few or didn't exist at all. Yet, this is arguably what happened in some cases, like the funerary landscapes analysed in central Iberia by Martín Viso and in northern Italy by Chavarría. In the former, communities occupying the Duero plateau existed in a context of extreme political fragmentation, in which funerary customs seem to respond strictly to the necessities of their social microcosms. Incorporation of the region into the Asturian kingdom in the late ninth and early tenth centuries apparently reordered the existing practices into a more uniform pattern, but following the Asturian retreat relapsed again into fragmented practices. The Italian example works at a different scale. The localities of the preCarolingian period were never as detached from state operation as those of the Duero plateau, but the funerary diversity that Chavarría describes seems to have declined as the Carolingians imposed a uniform religious culture of intense local capillary effect. In a similar vein, the economic and societal exchanges among rural communities that VigilEscalera describes for central Iberia look very much like a bottom-up phenomenon. The small rural centres that he studies provided religious, judicial and commercial functions for 
the surrounding communities. They reflect local networks of horizontal interaction, cooperation and co-dependence. They had also the potential to become suitable settings for interactions with supralocal agents who, at best, sought to benefit from those local developments once they were in operation.

The strategies discussed here have all explicitly considered the spatial dimensions of society, including the changing scales and hierarchies of territories, boundaries and settlements. In most of the studied regions there clearly existed territories-in the sense of spatialized social groupings-before there were states. In some cases, like Norway, these territories cannot be regarded as ghosts of earlier Roman administrative structures. In others, small territories, whether of remote Antique origin or not, functioned as the building blocks of secondary state formation. Part of the reason why local territories were so durable is because the local and regional identities with which they were associated were not exclusive; local identity could be nested within a series of wider-ranging identities. Beyond obvious cases of conquest by force, local people could foster notions of belonging to a larger group, both before such an identity coalesced into a state, and after the demise of former state organisation.

More tangible evidence for the practical reasons why people might entertain such ideas comes from the study of boundaries. Boundaries are often the most visible aspectsas historical records, as archaeological remains and landscape features-of local decisions, local government and local economy, and at the same time they are the objects of supralocal sanction and manipulation. After most evidence for the interfaces between the local and supralocal has disappeared, boundaries can still throw light on how groups define themselves, how decisions on resource allocation are made, and, importantly in the context of state formation, how such decisions can be given permanence through supralocal sanction. Even boundaries created at society's highest political spheres need to be pinned down in the local landscape, where they become one more component in defining locality. Many of the studies gathered in this book deal with different scales of boundaries, as expressions of both conflict and negotiation: how they come to exist; how they are maintained; whether they are enforced by government or by becoming embedded in local knowledge; how, once established, they become a locus for cooperation, competition and dispute; how, eventually, they disappear.

Finally, settlements - their shape, their size, and their hierarchies-emerge as one of the features that changed most intensely during the early Middle Ages. This underpins the fact that the long-term interactions between the local and the supralocal necessarily meant dramatic changes at both ends. Neither could remain the same. Mapping out settlement structures through time (e.g. locations, hierarchies, networks, catchments, borders), invariably reveals complex and dynamic interactions between them, suggesting that even in the absence of visible supralocal structures (churches, forts, top-level assembly sites) the neighbourhoods formed parts of larger wholes.

Across many of the papers in this volume observations are made about the types of interactions that existed above the neighbourhood but below those institutions of Church and polity that are normally seen as the embodiments of supralocal authority. Mostly, our case-studies demonstrate an absence of direct intervention, but at the same time they show that there existed a dynamic layer of interaction, representing common knowledge, practices and identities, that bound neighbourhoods together. Central places are detected in 
all contexts, be they seasonal assembly sites or markets, stand-alone rural churches servicing surrounding villages and farms, or market-towns and cities with complex institutions and neighbourhoods of their own. These middle scales are crucial nodes in the articulation between neighbourhoods and the top political spheres, and they can help us to understand the layered networks of identities, territorialities and knowledge that tie social actors together. Admittedly, these intermediate scales have received relatively little attention in this volume, and as such should be the focus for future reflection. There are surely many other potentially fruitful spatial phenomena that have not found a place in this volume, leaving the door open for more work to be done. Among them, we especially miss a thorough consideration of peripatetic kingship and other forms of travel that allowed top social actors to move across the landscape and make direct contact with the local. The construction of social distance and the remoteness of governance is obviously affected by this issue, even if it is unrealistic to equate governments on the move with less-developed states.

In conclusion, this book cannot claim to be anything more than a preliminary exploration of a set of processes that are extremely complex and difficult to reconstruct. It may, however, convey the message that, although historical records and archaeological remains are invariably fragmented, detailed investigation of the available evidence is both feasible and fruitful, even if much work remains to be done, both in terms of coverage and methodological approaches. It is maybe the main contention of this volume-and maybe that of this group's work over more than a decade-that looking at actual landscapes, actual monuments, actual fields, settlements and boundaries in their local context is necessary for understanding the highest political and ideological spheres and the broader social developments of the past.

\section{Bibliography}

Lönnroth, Erik, 'Government in Medieval Scandinavia', in Gouvernés et gouvernants, III: Bas moyen âge et temps modernes (I) (Brussels: Société Jean Bodin, 1966), pp. 453-60 